ROCZNIKI HUMANISTYCZNE

Tom LXIX, zeszyt 11 - 2021

ZESZYT SPECJALNY/SPECIAL ISSUE

DOI: https://doi.org/10.18290/rh216911-7s

\title{
THE POSITION OF MIDDLE IRISH: HISTORICAL LINGUISTICS AND GLOTTOCHRONOLOGY
}

\begin{abstract}
A b stract. A new method of "dating" language changes was proposed in the 1950s by Morris Swadesh $(1952,1955)$, who examined changes in the basic vocabulary of a language and postulated that the 1000 -year retention rate represents $86 \%$ of the vocabulary; in other words, 14 words from a 100-word list must be replaced. An attempt to calculate the split between Goidelic and Brittonic based on this approach was made in Greene (1964) and later in a fundamental study by Elsie (1979) containing, unfortunately, some inaccuracies. In Blažek and Novotná (2006) this split between Goidelic and Brittonic is dated to ca. 1200 BC. The authors used a new calibration, with a change in the constant of disintegration $\lambda$ from 0.14 to 0.05 per millennium, the elimination of borrowings and the inclusion of synonyms in the wordlist. The use of synonyms compromises the original Swadesh idea of the basic vocabulary of a language, and automatically leads to its artificial archaisation. This article tries to demonstrate the possibility of an analysis of semantic changes in basic Irish vocabulary using the non-modified version of the Swadesh method and to define a possible date for the growth of the Middle Irish language stratum.
\end{abstract}

Keywords: history of the Irish language; semantic shifts; language typology; glottochronology; semantic derivation; etymology.

\section{INTRODUCTION: GLOTTOCHRONOLOGY AS A METHOD: ITS VICTORIES AND DEFEATS}

Traditional historical linguists "don't do dates," as suggested by April and Robert McMahon in their interesting research on mathematics as applied to historical linguistics, titled Language Classification by Numbers. They even devote one blunt sentence to glottochronology as a branch of linguistics: "We

Prof. Dr Tatyana A. Mikhailova, Mikhail Lomonosov Moscow State University and the RAS Institute of Linguistics; e-mail: tamih.msu@mail.ru; ORCID: https://orcid.org/0000-0001-7867-6260. 
believe that glottochronology has been tested and found not only wanting but entirely invalid. By extension, there are reasons to be extremely skeptical at best of other supposed solutions to the dating problem in linguistics" (McMahon and McMahon 178).

It is true that linguists working with reconstructed languages "don't do dates." In dealing with well-attested "historical" languages, they usually try not only to determine specific stages or periods in the development of the language, but also to correlate them with important historical and social events. The well-known method called glottochronology, however, does try to create dates. Unfortunately, it is not, one might say, held in very high regard in wider linguistic circles.

This new and revolutionary method of "dating" language changes was proposed in the 1950s by Morris Swadesh, who examined the historical replacements in the basic vocabulary of any given language and proposed that the 1000 -year retention rate represents $86 \%$; in other words, about 14 words from a 100-word list would be replaced. This new technique of dating language changes was called lexicostatistics. "This apparently simple and elegant method was challenged as early as the 1960s and now has been all but discredited" according to Pereltsvaig and Lewis (94). This "simple" method of dating was modified (Sergei Starostin; Blažek; George Starostin) and to some degree compromised in Gray and Atkinson, who placed the separation of Goidelic and Brittonic as early as 2,900 years ago. James Mallory, in his book The Origins of the Irish, calls this technique "often cited but usually rejected" (Mallory 258). "We cannot help concluding that the lapis philosophorum of glottochronology is unable to transmute the baser metals of lexicostatistical numbers into pure gold of reliable dating. The radiocarbon method of dating is good for atoms, but is not good for culture-bound human languages" is how a nostratic linguist from Russia summarised the sceptical view of the lexicostatistical method (Dolgopolsky 404).

The claims that glottochronology as a method is not productive and cannot support the reconstruction of either linguistic relationships or language family trees are quite numerous. It is possible that the sceptical attitude to glottochronology is largely caused by the fact that, in works by various authors, the received data, which also involve dates, differ drastically. In this case, an article recently published by Sims-Williams is of great interest. ${ }^{1}$ In this, the

\footnotetext{
${ }^{1}$ I would like to use this occasion to thank my anonymous reviewer for referring to this exciting and informative work.
} 
glottochronology method, called "dubious" by the author, is used to prove the failure of the "Celtic from the West" theory, and the author points out, as a conclusion, the "unreliability of the linguistic evidence for 'Celtic from the West', namely (i) 'glottochronology"” (Sims-Williams 511).

This "dubious" method, used in the dating of linguistic divergence, however, finds its supporters (see, for example, Vasiliev and Saenko; Starostin, "Chinese Basic Lexicon"). It is for this reason that I found it interesting to test the validity of the hypothesis by applying it to the history of the Irish language data, namely to the shift from Old Irish to Middle Irish. Or, in the words of one of my Russian colleagues, speaking about the use of glottochronology in the history of Chinese:

The main goal of this paper is to advocate, once more, the use of the lexicostatistical method in both testing hypotheses of relationship and establishing the internal classification of well-demonstrated taxa. In general, I propose nothing new: ever since the popularization of lexicostatistics by Morris Swadesh in the $1950 \mathrm{~s}$, it has been used for these purposes over and over again, in many different ways and with widely varying results. (Starostin, "Chinese Basic Lexicon" 83)

\section{GLOTTOCHRONOLOGY AND THE CELTIC LANGUAGES}

The main grievance against the use of the lexicostatistical method for pinpointing the date of language divergence, and, more broadly, for any diachronic research, has been the inconsistency of the empirical data in the works by various authors. Thus, as Mallory points out, David Greene put the split between Q- and P-Celtic at about 700 BC (Greene 12), although in a study by Blažek and Novotná the separation of Goidelic, Brittonic and Gaulish is dated to ca. $1100 \mathrm{BC}$. Glottochronology gives us the beginning of the divergence process but not its result. I could add, for example, that in a 1971 article by Fowkes "the percentage of agreement (between Welsh and Breton) is 71" (Fowkes 192), which implies, according to the Swadesh formula of divergence, that these languages, or rather their ancestral dialects, had diverged by about the first century AD or even earlier, which seemingly flies in the face of historical evidence (the branching of Breton has been traditionally dated to the early fifth century AD and linked to the migration of some British tribes, driven out by the Saxons, to Armorica). As Paul Russell writes in An Introduction to the Celtic Languages, "[t]he distinction between Welsh on the one hand and Cornish and Breton on the other would seem then 
to belong to the fifth and sixth centuries, while features separating Cornish and Breton occur rather later" (Russell, An Introduction 128), which represents the traditional point of view. It is worth noting, though, that in a recent article he makes a new assumption: "We should also constantly remind ourselves that neither British nor Latin should be regarded as monolithic linguistic entities: the British spoken north of Hadrian's Wall, for example, was probably very different from that spoken in the south-west peninsula (and we do not know whether British was spoken at all by the late Roman period in the south-east)" (Russell, "Views of Multilingualism" 220).

In fact, I think, the "error" in Fowkes' work cited above may reflect the actual state of things, since the branching of Common Brittonic into dialects may well have begun before the British migration.

Sometimes, the inconsistencies in the specific calculation results, as noted by Mallory, originate primarily from a disagreement on the interpretation of the equivalents of the basic items themselves. Thus, in a comparative list of data for modern Irish and Scottish Gaelic, given in The Position of Brittonic by Elsie, I found eight obvious errors related both to inaccurate work with informants and to the wrong etymologisation of the data by the researcher himself. Below are some examples.

The verb to lie in his list received the Irish equivalent luigh-, but for Scottish Gaelic his equivalent is innis breug 'to say untrue things'. Thus, as we can see, the Scottish informant merely misunderstood which exact meaning of to lie the questionnaire suggested, yet, more significantly, Elsie himself did not notice it. In the same way, although in this case the error is less obvious, Elsie's Irish equivalent for English 'breast' is the word cioch, the meaning of which is specifically 'mammary gland', but for Scottish Gaelic he gives broilleach 'chest (regardless of sex)'. His equivalent of the Swadesh 'person' in Irish is duine (just like the Russian chelovek), but for Scottish Gaelic it is represented by neach 'somebody, anybody' (although the word duine 'a person, a man, an individual' is also attested in Scottish Gaelic, with basically identical meanings).

On the other hand, Elsie fails to recognise the match between Irish and Scottish Gaelic equivalents for feather-Mod. Ir. cleite, SG. ite, respectively, being unaware that in Irish, the anlaut cluster is a non-etymological later augmentation which appeared under the influence of the tendency towards forming pairs of alliterating synonyms or words of related meanings. Thus, the traditional phrase clum agus eite 'down and feather' was transformed into clum agus cleite. In Scottish Gaelic, there was no such transition. 
Another thing the author is unaware of is the shared etymology of the verbs for 'to say' in Irish and Scottish Gaelic: MI deir- and SG abair, respectively (both derive from the Old Irish verb as-beir > at-beir 'gives it out').

In other words, all of my eight corrections prove to be cases of finding more matches instead of divergences between the Irish and Scottish Gaelic Swadesh lists. Thus, Elsie calculated that "the distance between Irish and Scottish is 28\%" (Elsie 69). After my refinement, the proportion of divergences between the two languages drops and is now only 20 per cent, which corresponds to a branching point 1600 years before the present (according to Blažek it is 1100 $\mathrm{BC})$. And this is wonderfully supported by the historical evidence: the Goidelisation of Scotland began with sporadic migrations from north-western parts of Ireland (today's Ulster) in about the fifth to sixth centuries AD (on the colonisation of Dalriada, see Henderson 38-40; Laing 34).

\section{GLOTTOCHRONOLOGY: A PROBLEM OF MODIFICATION? OR: BACK TO SWADESH!}

The radical re-thinking of the Swadesh model, introduced by George Starostin, included, on the one hand, the very mathematical value of the so-called "constant" (the number of lexical replacements, rather than being constant, would change depending on the age of the reconstructed state of the language), and on the other hand, the systematic inclusion of synonyms for all attested languages in the 100-word list (which, by then, was 110 words for well-attested languages and 35 words for those poorly attested). Moreover, loanwords were excluded from the calculations. These changes are indeed justified where linguists deal with languages of an exotic sort, poorly described and/or of a problematic genetic affiliation. But studies in historical semantics, as such, must, in my opinion, be based exactly upon the concept of basic elements, standing at any given moment in the language's history behind the "relatively stable lexical items" as identified by Swadesh ("Lexico-Statistic Dating" 455). The language's history, thus, will be reduced to studies in lexical replacements, and the latter should be valid ones, with each borrowing from the donor culture being pinpointed. It is their validation which creates a separate problem, one which is naturally related to the lexicostatistical data, yet which is deemed an evaluation in its own right.

In this paper, I attempt to compare the relative rates of replacement of basic vocabulary items (from the 100-item Swadesh list) over specific checkpoints in 
the history of the Irish language: Early Old Irish and Late Middle Irish. After a concise explication of the methodology applied and a presentation of the data, I try to show that the average rates of replacement between each of these checkpoints do not significantly deviate from each other and are generally compatible with the classic "Swadesh constant" of 0.14 loss per millennium.

In the seminal article published by Vaclav Blažek and Lenka Novotná in the Journal of Indo-European Studies, the split between Goidelic and Brittonic is dated to ca. $1100 \mathrm{BC}$. The authors use a new calibration with a change in the constant of disintegration $\lambda$ from 0.14 to 0.05 per millennium, the elimination of borrowings and the inclusion of synonyms in the wordlist. The use of synonyms, I presume, compromises the original Swadesh idea of the basic vocabulary of a language, and automatically leads to its artificial archaisation (thus, the change in $\lambda$ ). Whilst good for "exotic" languages whose genetic kinship is not clear, this method does not suit "historical" languages from well-known language families. In such cases, the linguist does not need to build genealogical trees based on the percentages of cognates on the wordlist but assigns more precise dates to the nodes of languages separation. And if we look at the innovations proposed by Starostin and Blažek, and in particular the wide use of synonyms, we understand that their calibration does not contradict Swadesh. If we are speaking about a basic lexicon, of course, the replacement could be swifter than the total elimination of a lexeme. For example, in Russian we have a change in the item eye-a Scandinavian borrowing glas (a glass bead), which now has basic status, but at the same time cognates of IE ${ }^{*} o k^{w} o s$ - remain in the modern language: in the poetic word $o k o$, and also in ochki 'glasses' and ochevidnyj 'certain'.

Thus, glottochronology, being a supplement or "add-on" to lexicostatistics, could be seen as a self-valuable field, one which not only "does dates" but can also describe the mechanisms of semantic changes. The study of a short period in the history of a well-attested language can produce interesting results and demonstrate some "dead-end branches" in its development.

\section{4. "BASIC ITEM"-A PROBLEM OF DEFINITION}

The proponents of the use of lexicostatistical data for pinpointing the age of language family branching, as well as for the genetic classification of scarcely attested and/or scarcely described languages, are unaware, it seems to me, that the very work they are doing - that is, making etymologised and 
relatively well-dated lists - is of great value for studying regular semantic shifts. ${ }^{2}$ First, one issue that can be raised is the reason why this or that word has lost the status of "basic" (which does not necessarily mean the overall loss of its cognates in this language). Second, the original semantics of the words which have become "basic" in place of those which were lost may provide material for further comparative research.

The selection of a "basic item" from amongst the close synonyms of a language presumes the solution to two different problems. First,

[o]ne important feature that has made the Swadesh wordlist so popular among linguists is its relative simplicity and transparency. However, that same simplicity-each item is defined by a single English word - in many particular situations comes across as a significant flaw, since the words have been originally listed without any specific comments or explanation.... Sometimes the ambiguous selections that researchers undertake at their personal initiative violate the very purpose of the 100-wordlist. For instance, in a vast majority of particular studies the slot 'breast' is filled in with the equivalent for 'female breast(s)'; however, the meaning 'female breast(s)' in the world's languages is very frequently expressed by various baby-talk ... formations that can hardly serve as reliable comparanda in one's investigation of language relationship. (Kassian et al. 46-47)

Second, what "item" can we call "basic" in the historical development of a language? When does a lexeme become a simple, neutral equivalent of a semantic concept and displaces its archaic synonym? The authors of the aforementioned article write:

In all cases, as is prescribed by the standard procedure, we advocate the choice of the most stylistically basic, neutral, and unmarked word, unencumbered by either pragmatic connotations or strongly emphasized additional, "extra" semantic features. Thus, belly is used instead of abdomen ("scientifically colored" talk), paunch (referring to a specific type of belly, often "emotionally marked") or tummy (colloquial or "baby talk") for the Modern English 100-wordlist. (Kassian et al. 48)

But what is easy to find and to define for modern, well-attested living languages, having good dictionaries and many native speakers with some "linguistic intuition" (for help), becomes a real problem for old and/or dead languages, attested only in manuscripts. I suppose, in my case, the correct solution would be to qualify as "neutral" the (a) non-metaphoric and (b) nonrestricted use of a lexeme. For example, the word bóthar is attested in the

\footnotetext{
${ }^{2}$ For more on "regular or recursive" semantic shifts, see Zalisniak et al.
} 
Glossary (late 9th cent.), attributed to Bishop Cormac Ua Cuilennán. Notably, the author of the glossary sees the word's inner form quite clearly:

Bōthar, talla dā boin fair .i. alanāi for fot, alaile fortarrsnae, ara talla a llōigu $\urcorner$ a ngamna ina farad, ar mad ina ndīaid beit iurthass in bō bias dia èis-A bóthar, two cows fit upon it, i.e. one lengthwise, the other athwart, for their calves or their yearlings fit on it along with them, but if they [the calves] were behind them [the cows], the cow that followed would gore. (Meyer 96)

In Modern Irish, the word bóthar is only attested in the meaning of 'road'; it is neutral and has no specifications. But Bishop Cormac gives a clear commentary and reveals the inner form of this lexeme: the passage of cows. ${ }^{3}$ Thus, we could presume, the change of basic denotation of 'road' from slige to bóthar dates to a later period in Irish.

\section{MIDDLE IRISH: A PROBLEM OF DETERMINATION}

The Middle Irish period (ca. 800-ca. 1100), traditionally associated with the Viking invasions, has been described in detail with regard to its orthography, phonology, morphology, verbal system and syntax (the rise of the copula, the loss of the neuter gender, the new system of personal pronouns, the vocalisation of glides, etc., see Breatnach; McCone, A First Old Irish Grammar, including the references therein). The semantic development of Irish lexica, the systematic changes in its vocabulary from the early period (Old Irish, 600-800) to the later one (Middle Irish) did not interest linguists, however, with the exception of Latin and Norse borrowings. The analysis of changes in the Irish basic wordlist could be an important step towards fulfilling this lack of research.

There seems to be a general understanding that conducting lexicostatistical studies is an important stage in unravelling the internal history of Irish and identifying certain key points resulting in divergent linguistic lineages, as well as separating the evidence for genetic splits from the evidence for later linguistic contacts that tend to obscure the different lineages in question.

Returning to the classical Swadesh method, excluding synonyms in the supposed basic items and, on the contrary, including borrowings, I counted ten supposed or presumed changes. Thus, for a period of circa 400 years, the list is too long; according to Swadesh, it should contain only five or six items.

\footnotetext{
${ }^{3}$ On the synonyms of 'road' from a historical perspective, see Mikhailova (in print); on the synonyms of 'road' in Old Irish, see Doherty.
} 
The $90 \%$ retention rate corresponds to a period of 720 years (according to the Swadesh $\lambda$-constant of disintegration). The simplest idea-that the glottochronology technique automatically extends the MI period to the sixteenth century - is false. Not because of the traditional determination of "stages" in the history of Irish, but because of later, new changes in its basic vocabulary (cú-madra 'dog', folt-gruaig 'hair', escae-gealach 'Moon', sligebóthar 'road' etc.). The aim of my paper is to try to resolve this problem, to demonstrate the real relationship between Old and Middle Irish, and to answer the question of whether the MI period really represents a "stage" in the continuum of permanent language development.

\section{OI > MI: SEMANTIC SHIFTS AND BASIC LEXICON}

The arithmetic average of all shares between Classical Old Irish (7-9 cent.) and late Middle Irish (12 cent.? $)^{4}$ gives 0.90 , so we have ten (problematic and supposed) changes:

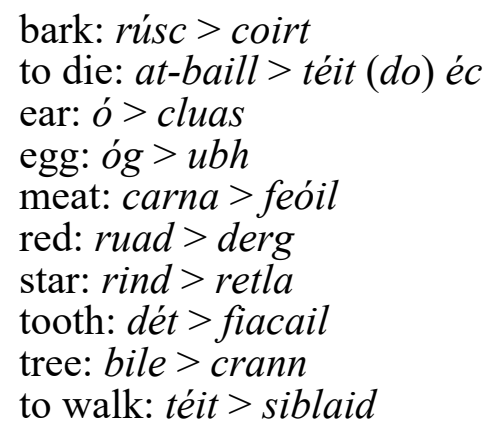

This does not mean, of course, that all of these lexemes were not in use in the MI period (and later), but that they had lost their basic neutral status. Each change deserves a discussion and needs a supposed motivation based on cultural changes in the Irish mentality and way of life. ${ }^{5}$

Bark: rúsc > coirt

The Old Irish word for the item 'bark' was rúsc (with an unsure etymology; see Matasović 317). In the Middle Irish period, the lexeme received, by

\footnotetext{
${ }^{4}$ On the different traditions in the periodisation of Irish, see Rockel (25-29).

${ }^{5}$ A more detailed and necessary analysis is beyond the scope of this article.
} 
extension, the meaning 'receptacles made of bark' (vessels, butter tubes, etc.). The semantic 'bark of a tree, bark as material' was filled by a Latin borrowing: coirt < cortex, leaving for rúsc the use in phraseological combination rusc agus duile 'bark and leaves'. See the neutral use in MI medical tracts: coirt sailech, coirt darach 'bark of willow tree, of oak'.

To die: at-baill > téit (do) éc, MI écaid 'dies'

Lexicon of this kind is generally fluent and not stable, I suppose, because of the importance of the subject itself, so language tries to use euphemisms for some denotations and to invent periphrastic changes and replacements. The Irish language even now preserves the old IE root for death, but it became the adjective marbh and, as far as the verb is concerned, the causative 'to die' was transformed into 'to kill'-OI marbaid. If we try to find an equivalent denoting not violent, but natural death in OI, it gives the verb at-baill, which etymologically means 'to be extended'. Later, another old IE root for 'to die' was used, i.e. éc-, which was transformed into a MI verb, preferably used in the past tense: d'eag sé or téit (do) éc. This item is not stable and, I could add, in Modern Irish was replaced by the phrase fuair sé bás and other periphrastic words (see Mikhailova and Nikolaeva).

Ear: OI $a u, \bar{o}>$ MI clüas

Both lexemes are of Celtic origin. According to Vendryes, the word au, later $o$, was preserved only in poetic language ("vieux mot conserve en poésie, mais remplacé de bonne heure par cluas"-Vendryès, Lexique etymologique de l'irlandais ancien 102), and the compilers of DIL also mark this word as obsolete and confined to heroic literature. The word has an IE etymology and has cognates in other modern IE languages; for example, the Russian ukho, plural ushi, derives from the IE root*ous-, preserved in the Slavonic languages, from Common Slavonic *uxxo (see Derksen 507). Matasović proposes a derivation from the Common Celtic stem *awsos-, which has cognates only in OI and, supposedly, in the Gaulish personal name Su-ausia, 'having good ear' (Matasović 48). But we must add that, even in Gaulish, an old IE root could be replaced by derivations from the IE verbal root 'to hear, listen', for example Matrebo rocloisiabo 'for mothers having ears', or maybe 'listening' (Delamarre 262). In Welsh, we also have a derivation from the verbal stem - clust 'ear', as well as in Old Norse-hlust 'the same', from the 
IE base *k'leus- ${ }^{6}$ This semantic shift (verb—process—organ) is surely logical. But the motivation of the replacement is not so clear. The old root is preserved in Balto-Slavonic and in the Romance languages but was replaced in Celtic and partly in Germanic. We could infer some social changes, because the motif of tabulation in this case is not a good explanation.

Egg: OI $o ́ g>$ MI $u b h$

The Old Irish word for egg represents a cognate from the common IE root *owyo-, connected, as many historical linguists suppose, with the IE name of the bird *awi-s (see Mallory and Adams 76). Vendryès (Lexique etymologique de l'irlandais ancien. $M, N, O, P \mathrm{O}: 13$ ) supposes that both the lexemes óg and the later form $u b h$ come from the same IE root, but, by extension, the first form received the meaning 'testicle' and the second form appeared for tabulation. The meaning 'testicle' is attested in OI and in MI texts, glossed as genitalia. The lexeme is traditionally used in its old form ó $g$ in narratives and poetry, but in MI law and medical tracts the egg of the bird is represented as $u b h$. The MI form $u b h$ could be influenced by the word ubull 'apple', and later 'any round object' (as well as Latin ovum).

Meat: OI carna > MI feóil

Early Irish presumably had no distinction between 'flesh' and 'meat', as in Modern Irish, but in the Old Irish period a Latin word was borrowed to designate 'meat for eating': carnae. This lexeme is widely attested in Old and even Middle Irish narratives, but "the distinction is not always observed" (eDIL). See the two versions of the Death of Cú Chulainn:

OI: Geiss dó dano cárna a chomanma do ithi-

'It was a taboo for him to eat the meat of his namesake.' (Kimpton 18, 1. 235)

MI (or Early Modern Irish): d'fheoil con allta-

'from the flesh (meat?) of the wolf (wild dog?)' (Van Hamel 98)

Red: OI ruad > MI derg

As in other IE languages, the old root for 'red' was outset to the marginal zone of nature and described the colour of hairs, the bark of some trees and animal fur. Modern Irish rua(dh) is also attested in many personal names.

\footnotetext{
${ }^{6}$ For an analogic semantic shift in the history of Chinese, see Starostin ("Chinese Basic Lexicon").
} 
An interesting testimony from the MI tract 'The Pseudo-Historical Prologue to Senchus Mor', could illustrate this shift. The compiler speaks of the colours of the winds created by God, so they represent a chromatic system, and we can see that, between corcra 'purple' and buide 'orange' or 'yellow', it contains a derg wind, and the word ruad is not mentioned in this system:

Ro delb dó na hocht ngaetha .i. .iiii. primgaetha $\rceil$ ceithri fogaetha.

Ro delb dó datha na gaeth, conid sain dath cacha gaeithe dib fri araile i. gel $\rceil$ corcra,

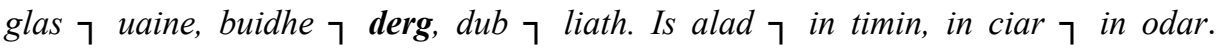
[CIH: 343] - 'He created eight winds, four first-winds and four sub-winds. He created colours of winds, so each wind differs from another, bright and purple, green and dark green, yellow and red, black and grey. Also speckled and dark, dark grey and brown.'

Regarding the winds' description in the law tract and in the poetic tract Saltair na Rann as a modern colour spectrum, see Siewers (99-102).

The existence of derc as a basic term for 'red' could be, though, illustrated by its use in the Cambrai Homily, a combination of Old Irish and Latin and dated to some time around 700; speaking about three kinds of martyrdoms the author uses the basic terms báanmartre, ocus glasmartre ocus dercmartre (Stokes and Strachan 246). ${ }^{7}$ Thus, this change could be dated earlier.

Star: OI rind $>$ MI retla

A common term for heavenly bodies in Early Irish is rind $(\mathrm{u}, \mathrm{n})$, gen. rendo, which eDIL broadly defines as 'constellation, star; planet' (s.v. eDIL 2 rind dil.ie/35319). However, the editors of the dictionary specify that "the orig[inal] meaning may be that of Lat. signum [i.e. 'constellation'] which it glosses Sg. 69a6, M1. 2a14; prob[ably] influenced by 1 rind [i.e. 'point, tip, end, extremity'] in its development. In later language generally confined to poetry" (eDIL).

The MI poetic tract Saltair na Rann abundantly bears out the specific semantics of, and the distinction between, the two words. I will cite just a few representative examples. Canto I, 101-4 illustrates the notion that those heavenly bodies that possess a sphere of their own are ranked among the renda:

\footnotetext{
${ }^{7}$ I would like to take this opportunity to express my gratitude for this observation to my anonymous reviewer. The development of the semantic field 'red' in Irish deserves a special study (see also Stifter, "Study in Red").
} 
Ro'suidig secht rinn, réim [cain],

ó firmimint co talmain:

Satuirn, Ióib, Mercúir, Mars

Sol, Uenir, Luna lánmas.

'He established seven heavenly bodies (rinn),

a (good) course, from the firmament to the earth:

Saturn, Jupiter, Mercury, Mars,

the Sun, Venus, the very beautiful Moon.'

Similar ideas are found in SR 131, 202, 1801. The same tally of seven renda is made in Canto CLII, 7921-4, where, at the same time, renda and rétglainn are juxtaposed:

Cía lín na rétlann ad·rann

mod mall fria rím ós cech dind?

Rethait frithrosc iar sét sain,

cid cotas'gaib na secht rind?

'What is the number of the stars (rétlann) which he kindled,

it is slow work counting them over every height?

They run backwards (?) on a separate path;

what holds up the seven stars (rind)?'

Rétglu, gen. rétglann $(\mathrm{n}, \mathrm{f})$ 'star' was the ordinary Old Irish word for a single star which is not of importance for time keeping or orientation. In the course of time, it encroached upon rind and ultimately replaced it completely. In MI, the medial cluster was first simplified to rétla, and then became rélta through metathesis. It eventually yielded Mod Ir. réalt, the common word for 'star'. For more on this semantic development, see Stifter ("The Stars").

Tooth: OI dét > MI fiacail

The IE derivation of the lexeme for 'tooth' *dont- (W. dant, Bret. dant) gave OI dét, and was widely used in descriptions of beautiful people; in the descriptions of ugly personages having black teeth, another word was used, whose literary form represented the name of the spade: Early Irish fecc, which in the early period received the meaning 'tooth' in a suffixed form. The word fiacail is attested in neutral contexts in MI lives and saga narratives. For example, from the story about Niall and the sons of Eochaid, in The Yellow Book of Lecan: 
Fiacla niamda nemannda le, $\urcorner$ rosc rignaide romor, $\urcorner$ beoil partardeirg -

'Shining pearly teeth she had, an eye large and queenly, and lips red as rowanberries.'

(Stokes 200)

In the MI period, dét and fiacail were used as synonyms. The motivation of the replacement could be interpreted, I suppose, by social changes and traditional literary orientations. Therefore, the old IE root could have sophisticated connections, whilst the word derived from 'spade' belonged to popular speech.

\section{Tree: OI bile > MI crann}

This replacement is rather dubious. It is not easy to propose an equivalent for this item in OI because in the early period there existed two equivalents with some semantic difference. Bile had the meaning of an isolated tree, a tree trunk, while crann, used in the language of the Glosses, had a more general meaning. The word crann derives from the Common Celtic form ${ }^{*} k^{w} r e s n o-$ 'wood, tree', which gives W. pren 'tree' and is also attested in Gaulish (in the Endlicher Glossary: prenn i.e. arborem grandem; see Delamarre 252). At the same time, bile also has Gaulish parallels attested in placenames, for example Billiomagus. The word bile is also attested in Ireland in placenames and is used in the names of the five sacred trees of Ireland, for example Bili Tortan and Bili Da Thi. Thus, bile could be considered an archaic word, used as a synonym with crann, but later became a poetic word, not of popular use.

To walk: OI téit (?) > MI siblaid

“The original Swadesh item 'to walk', referring either to movement with specific direction (walking in the park) or emphasizing the idea of using one's feet rather than any means of transport, was rather ambiguous and tended to be replaced by 'to go' already in the early wordlists; we recommend this tradition" (Kassian et al. 62). I object to this recommendation because of the existence of the specific verb 'to walk' in Modern Irish and in Gaelic. The verb 'to walk' really did not exist in OI, and the idea of walking on feet was expressed by the simple verbs of motion téit and do-tét. At the same time, the verbal noun sibal with the meaning of 'moving, travelling, walking' and also 'a military expedition, a journey' was attested in OI. In late MI, a verb was composed from this noun-siblaid 'to travel, to walk'. In Modern Irish, the form siúl is used with the same meaning. The etymology of sibal is dubious; 
the proto-form * stebulo- could be from the same root that gives the word 'step' in Germanic (Vendryès, Lexique étymologique de l'irlandais ancien: Lettres $R$ S S: 104). In Scottish Gaelic, we have another derivation for 'to walk' - cosaid, from the word cois 'foot'.

As a result, we have 10 replacements over approximately 400 or 500 years, which exceeds the Swadesh calculations ( 0.14 loss per millennium or the "lambda constant"). In my study, I have proposed a simple solution to this lexicostatistics "paradox," thinking of Old Irish and Middle Irish as two completely independent developments from Primitive Irish (not strictly the "language of Ogham inscriptions," but rather spoken forms of the language of this period). My idea is presented in figure 1, drawn as per my own calculations by my colleague from the Institute of Linguistics, Dr Oleg Mudrak:

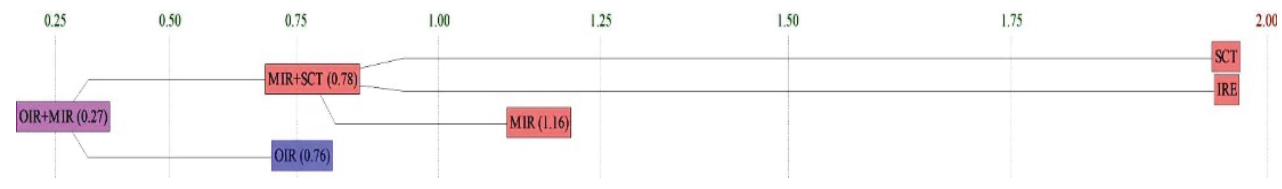

Figure 1. Old Irish and Middle Irish as independent developments from Primitive Irish.

The idea that Middle Irish is not a direct continuation of Old Irish is not, by itself, new. In a table from the popular book The Irish Language (Ó Murchu 54) we see not a smooth line, but rather a stepped curve, from the literary forms of the language to the spoken forms (see figure 2):

\footnotetext{
${ }^{8}$ I would like to take this opportunity to express my gratitude for his help.
} 


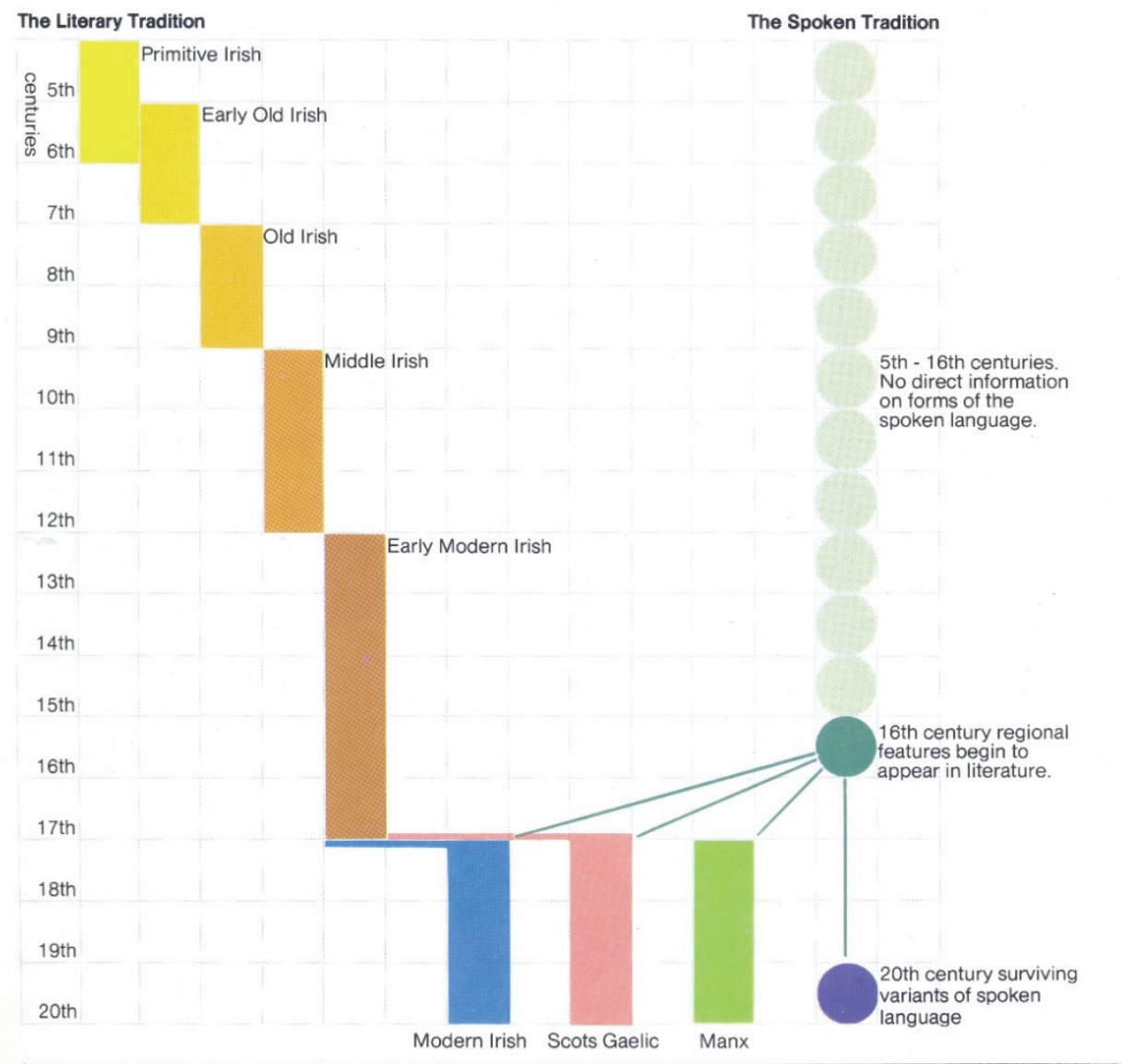

Figure 2. A pattern of chronological and regional variants of the Irish language.

Many of the developments which we associate with the Middle Irish period can already be seen in their embryonic stage in Old Irish, and this fact prompted McCone to give his work the seemingly perverse title "The Würzburg and Milan Glosses: Our Earliest Sources for 'Middle Irish'." The author concludes that classical Old Irish was an upper register from which scholars would occasionally slip into what must have been becoming increasingly more common at the lower levels of speech. At the same time, as we might understand, language registers tend to coexist, and people (speakers and scribes) could command, or at least understand, two registers. 


\section{A PRELIMINARY CONCLUSION}

1. Middle Irish is not a "stage" or a "period" in the history of the Irish language but represents a specific variety of the written language preserved in manuscripts. Old Irish also represents not a stage, but a specific and maybe artificial, non-spoken form of the language. It is interesting to note that "[a] gloss on the Amra in Lebor na hUidre uses the expression isin tengoedilg, 'in the old Irish', clearly acknowledging a linguistic boundary" (Herbert 97) for the speakers.

2. Both Middle and Old Irish coexisted with forms of the real living language, having dialectal and sociolectal varieties. Modern Irish, as well as Modern Gaelic, do not derive from MI, but arise from oral dialectal (?) forms of the language-continuum. MI, as well as OI, are rather "dead-end branches." This conclusion, I must say, was partly influenced by the study of the history of Chinese basic lexicon as proposed by Starostin ("Chinese Basic Lexicon").

3. I would suppose that the further development of my method, deriving from glottochronology, should represent the possibility of dating texts not only by their grammar, but also by the semantics of the lexemes used. It is uncomplicated when, for example, we are speaking about Scandinavian loanwords (their presence in a text could be testimony of its late date). But, for example, when we find in a text the word fiacla, not with the meaning of 'small spades', but rather 'teeth', we also can draw a conclusion on the late dating of its origin. "Hopefully, the present study takes a small step in this direction" (Starostin, "Chinese Basic Lexicon” 175).

\section{WORKS CITED}

An Electronic Dictionary of the Irish Language, 2019, based on the Contributions to a Dictionary of the Irish Language, Royal Irish Academy, 1913-1976. www.dil.ie. Accessed on 24 Nov. 2020.

Blažek, Václav. "From August Schleicher to Sergei Starostin: On the Development of the TreeDiagram Models of the Indo-European languages." Journal of Indo-European Studies, vol. 35, no. 1, 2007, pp. 82-109.

Blažek, Václav, and Petra Novotná. "On Application of Glottochronology for Celtic Languages." Linguistica Brunensia, vol. 54, 2006, pp. 71-100.

Breatnach, Liam. “An Mheán-Ghaeilge.” Stair na Gaeilge, edited by Kim McCone et al., St. Patrick’s College, 1994, pp. 61-220.

Delamarre, Xavier. Dictionnaire le la langue gauloise. Une approche linguistique du vieux-celtique continental. Éditions Errance, 2003.

Derksen, Rick. Etymological Dictionary of the Slavic Inherited Lexicon. Brill, 2008. 
Doherty, Charles. "A Road Well Travelled: The Terminology of Roads in Early Ireland." Clerics, Kings and Vikings. Essays on Medieval Ireland in Honour of Donnchadh Ó Corráin, edited by Emer Purcell et al., Four Courts Press, 2015, pp. 21-30.

Dolgopolsky, Aharon B. "Sources of Linguistic Chronology." Time Depth in Historical Linguistics, edited by Colin Renfrew et al., McDonald Institute for Archeological Research, 2000, pp. 401-409.

Elsie, Robert W. The Position of Brittonic: A Synchronic and Diachronic Analysis of Genetic Relationships in the Basic Vocabulary of Brittonic Celtic. Rheinische Friedrich-WilhelmsUniversität, 1979.

Fowkes, Robert A. “Glottochronology and Brythonic?” Studia Celtica, vol. 6, 1971, pp. 189-194.

Gray, Russell D., and Quentin D. Atkinson. "Language-Tree Divergence Times Support the Anatolian Theory of Indo-European Origin." Nature, vol. 426, 2003, pp. 435-439.

Greene, David. “The Celtic Languages.” The Celts, edited by Joseph Raftery, Mercier, 1964, pp. 9-21.

Henderson, Isabel. The Picts. Thames and Hudson, 1967.

Herbert, Máire. "Crossing Historical and Literary Boundaries: Irish Written Culture Around the Year 1000." Crossing Boundaries. Croesi Ffiniau. Proceedings of the XIIth International Congress of Celtic Studies, 2003, University of Wales, Aberystwyth, edited by Patrick Sims-Williams and Gruffyd Aled Williams, U of Wales, CMCS, 2007, pp. 87-104.

Kassian, Alexei, George Starostin, Anna Dybo, and Vasiliy Chernov. "The Swadesh Wordlist. An Attempt at Semantic Specification.” Journal of Language Relationship, vol. 4, 2010, pp. 46-89.

Kimpton, Bettina, editor. The Death of Cú Chulainn. A Critical Edition of the Earliest Version of Brislech Mór Maige Muirthemni. National U of Ireland, 2009.

Laing, Lloyd, and Jennifer Laing. The Picts and the Scots. Sutton Publishing, 1993.

Mallory, James. The Origins of the Irish. Thames \& Hudson, 2013.

Mallory, James, and Douglas Adams. Encyclopedia of Indo-European Culture. Fitzroy Dearborn, 1997.

Matasović, Ranko. Etymological Dictionary of Proto-Celtic. Brill, 2009.

McCone, Kim. "The Würzburg and Milan Glosses: Our Earliest Sources for MI.” Ériu, vol. 36, 1985, pp. 85-106.

McCone, Kim. A First Old Irish Grammar and Reader, Including an Introduction to Middle Irish. National U of Ireland, 2005.

McMahon, April, and Robert McMahon. Language Classification by Numbers. Oxford UP, 2005.

McMahon, April, and Robert McMahon. "Why Linguists Don't Do Dates: Evidence from IndoEuropean and Australian Languages." Phylogenetic Methods and the Prehistory of Languages, edited by Peter Forster and Colin Renfrew, McDonald Institute Monographs, 2006, pp. 153-160.

Meyer, Kuno, editor. Sanas Cormaic - Cormc's Glossary. Anecdota from Irish Manuscripts, vol. 5. Halle a.S. Niemeyer, 1913.

Mikhailova, Tatiana, and Natalia Nikolaeva. "The Denotation of Death in Goidelic: To the Question of Celtic Eschatological Conceptions.” Zeitschrift für celtische Philologie, vol. 53, 2003, pp. 93-115.

Mikhailova, Tatiana, "How to Say 'Road' in Irish: Towards Determining and Semantic Derivation of Words Conveying the Idea of 'road' in the Basic Swadesh Lists of Continental/Insular Celtic." Studia Celto-Slavica. Journal of the Learned Association Societas Celto-Slavica, vol. 12, 2021 (in print).

Ó Murchu, Máirtín. The Irish Language. Dublin Department of Foreign Affairs and Bord na Gaeilge, 1985. 
Pereltsvaig, Asya, and Martin W. Lewis. The Indo-European Controversy. Facts and Fallacies in Historical Linguistics. Cambridge UP, 2015.

Renfrew, Colin. "Early Celtic in the West: The Indo-European Context." Celtic from the West 2: Rethinking the Bronze Age and the Arrival of Indo-European in Atlantic Europe, edited by John T. Koch and Barry Cunliffe, Oxbow Books, 2013, pp. 207-218.

Rockel, Martin. Grundzüge einer Geschichte der irischen Sprache. Verlag der Österreichischen Akademie der Wissenschaft, 1989.

Russell, Paul. An Introduction to the Celtic Languages. Longman, 1995.

Russell, Paul. "An habes linguam Latinam? Non tam bene sapio: Views of Multilingualism from the Early Medieval West." Multilingualism in the Graeco-Roman Worlds, edited by Alex Mullen and Patrick James, Cambridge UP, 2012, pp. 193-224.

Siewers, Alfred K. Strange Beauty. Ecocritical Approaches to Early Medieval Landscape. Palgrave Macmillan, 2009.

Sims-Williams, Patrick. "An Alternative to 'Celtic from the East' and 'Celtic from the West'." Cambridge Archeological Journal, vol. 30, no. 3, 2020, pp. 511-529.

Starostin, George. "Preliminary lexicostatistics as a basis for language classification: A new approach". Journal of Language Relationship, vol. 3, 2010, pp. 79-116.

Starostin, George. "Chinese Basic Lexicon from a Diachronic Perspective: Implications for Lexicostatistics and Glottochronology.” Journal of Language Relationship, vol. 17, no. 2, 2019, pp. 153-176.

Starostin, Sergei. "Comparative-Historical Linguistics and Lexicostatistics.” Historical Linguistics and Lexicostatistics, edited by Vitaly Shevoroshkin and Paul Sidwell, Association for the History of Language, 1999, pp. 3-50.

Stifter, David. "Study in Red." Die Sprache. Zeitschrift für Sprachwissenschaft, no. 40, 1998, pp. 202-223.

Stifter, David. "The Stars Look Very Different Today.” Ériu 68, 2018, $29-54$.

Stokes, Whitley, editor. "Echtra Mac nEchach Muigmedóin: The Adventures of the Sons of Eochaid Muigmedóin." Revue Celtique, vol. 24, 1903, pp. 190-203.

Stokes, Whitley, and John Strachan, editors. Thesaurus Palaeohibernicus. Vol. 2, Cambridge UP, 1903.

Swadesh, Morris. "Lexico-Statistic Dating of Prehistoric Ethnic Contacts." Proceedings of American Philosophical Society, vol. 96, 1952, pp. 452-463.

Swadesh, Morris. "Towards Greater Accuracy in Lexicostatistic Dating." International Journal of American Linguistics, vol. 21, 1955, pp. 121-137.

Van Hamel, A. G., editor. Compert Con Culainn and Other Stories. Dublin Institute for Advanced Studies, 1978.

Vasilyev, Mikhail, and Mikhail Saenko. "How Accurate can Glottochronology Be? Dating the Lexical Replacement Process in the Romance Languages." Journal of Language Relationship, vol. 14, no. 4, 2016, pp. 259-278.

Vendryès, Joseph. Lexique etymologique de l'irlandais ancient. A. Dublin Institute for Advanced Studies, Centre National de la Recherche Scientifique, 1959.

Vendryès, Joseph. Lexique etymologique de l'irlandais ancien. $M, N, O, P$. Dublin Institute for Advanced Studies, Centre National de la Recherche Scientifique, 1960. 
Vendryès, Joseph. Lexique étymologique de l'irlandais ancient. $R, S$. Dublin Institute for Advanced Studies, Centre National de la Recherche Scientifique, 1974.

Zalizniak, Anna A., et al. "The Catalogue of Semantic Shifts as a Database for Lexical Semantic Typology.” Linguistics, vol. 50, no. 3, 2012, pp. 633-669.

\section{POZYCJA JĘZYKA ŚREDNIOIRLANDZKIEGO: JEZYKOZNAWSTWO HISTORYCZNE A GLOTTOCHRONOLOGIA}

Streszczenie

Morris Swadesh $(1952,1955)$ zaproponował nowa metode datowania zmian językowych, która zakładała 1000-letnią retencję 86\% słownictwa, tzn. 14 słów (z listy 100 podstawowych) musi być zastąpione. Przy jej użyciu Greene (1964), a następnie Elsie (1979), podjęli próbę określenia, kiedy nastąpił podział na grupę goidelską oraz brytańską. Blažek i Novotná (2006) datują to wydarzenie na okres ok. 1200 p.n.e., gdyż użyli nowej kalibracji, zmieniając stałą dezintegracji $\lambda$ z 0.14 na 0.05 na millennium, wyeliminowali zapożyczenia oraz uwzględnili synonimy w liście słów. Użycie synonimów zaprzecza oryginalnej idei Swadesha, która zakładała listę podstawowego słownictwa, oraz automatycznie prowadzi do sztucznej archaizacji. W artykule pod rozwagę poddaje się możliwość analizy zmian semantycznych w podstawowym słownictwie irlandzkim przy użyciu oryginalnej metody oraz podjęto próbę oszacowania wzrostu średnioirlandzkiej warstwy językowej.

\section{Przektad angielskiego abstraktu} Maria Bloch-Trojnar

Słowa kluczowe: historia języka irlandzkiego; zmiany semantyczne; typologia języka; glottochronologia; derywacja semantyczna; etymologia. 